\title{
Motivasi, Kepuasan Kerja, Komitmen Pegawai Akuntansi dan Kualitas Laporan Keuangan Pemerintah Daerah pada Pemerintah Kota Depok
}

\author{
Baja Lodhrakentjana ${ }^{1}$, Elvira Luthan ${ }^{2}$ \\ ${ }^{1}$ Universitas Pancasila, Jl. Srengseng Sawah, Jagakarsa, Jakarta Selatan 12640 \\ ${ }^{2}$ Universitas Andalas, Jl. Limau manis, Kecamatan Pauh, Sumatera Barat 25163
}

I N F O A R T I K E L

JEL Classification:

H53

Keywords:

motivation, job satisfaction, commitment, accounting employee, quality of local government financial report.

\section{$A B S T R A C T$}

Public demand for good governance is increasing. This encouraged the central government and local governments to implement the public accountability. One indicator of the performance of local governments in the field of financial management indicated on the output of the quality of the financial statements are realized by the opinion of local government financial statements based on the audit by the Supreme Audit Agency (BPK). This study aimed to examine the effect of motivation, job satisfaction and commitment to quality financial statements regional governments made by employees who handle accounting on regional work units and the Regional Finance Management Unit (SKPD and SKPKD) Depok city government. Data analysis was performed using Structural Equation Modeling (SEM) with aid Linear Structural Relations (Lisrel). The results show that the motivation, job satisfaction and commitment is positively related and significant effect on the quality of financial reporting.

\section{A B S T R A K}

Tuntutan masyarakat terhadap pengelolaan pemerintahan yang baik semakin meningkat. Hal ini mendorong pemerintah pusat dan pemerintah daerah untuk menerapkan akuntabilitas publik. Salah satu indikator kinerja pemerintah daerah di bidang pengelolaan keuangan ditunjukkan dari keluaran berupa kualitas laporan keuangan yang diwujudkan oleh opini laporan keuangan pemerintah daerah berdasarkan audit oleh Badan Pemeriksa Keuangan (BPK). Penelitian ini bertujuan untuk menguji pengaruh motivasi, kepuasan kerja dan komitmen terhadap kualitas laporan keuangan pemerintah derah yang dibuat oleh pegawai yang menangani akuntansi pada Satuan Kerja Perangkat Daerah dan Satuan Kerja Pengelola Keuangan Daerah (SKPD dan SKPKD) pemerintah kota Depok. Analisis data dilakukan dengan menggunakan Structural Equation Modelling (SEM) dengan bantuan Linear Structural Relation (Lisrel). Hasil pengujian menunjukkan bahwa motivasi, kepuasan kerja dan komitmen berhubungan positif dan berpengaruh signifikan terhadap kualitas laporan keuangan. 


\section{Pendahuluan}

Meningkatnya tuntutan masyarakat terhadap pengelolaan pemerintahan yang baik telah mendorong pemerintah pusat dan pemerintah daerah untuk menerapkan akuntabilitas publik. Tata kelola kepemerintahan yang baik berkaitan dengan upaya reformasi birokrasi, penegakan supremasi hukum, transparansi, kepedulian kepada pemangku kepentingan, akuntabilitas, visi strategis serta menuntut perubahan pola berpikir sebagaimana dinyatakan dalm buku Rencana Pembangunan Jangka Menengah Daerah Provinsi Jawa Timur Tahun 2009-2014. Akuntabilitas adalah sebagai bentuk kewajiban mempertanggungjawabkan keberhasilan atau kegagalan pelaksanaan misi organisasi dalam mencapai tujuan dan sasaran yang telah ditetapkan sebelumnya melalui suatu media pertanggungjawaban yang dilaksanakan secara periodik. Salah satu indikator kinerja pemerintah daerah di bidang pengelolaan keuangan ditunjukkan dari keluaran berupa kualitas laporan keuangan yang diwujudkan oleh opini laporan keuangan pemerintah daerah berdasarkan audit oleh Badan Pemeriksa Keuangan (BPK). Kriteria atau tolok ukur yang digunakan oleh BPK dalam melakukan pemeriksaan keuangan dalam rangka pemberian opini tersebut didasarkan pada peraturan perundang-undangan di atas. Guna mendapatkan opini laporan terbaik, para pihak terkait dengan pengelolaan keuangan daerah dan penyusunan laporan keuangan daerah harus memahami dan menerapkan ketentuan tersebut dengan baik.

Perkembangan opini BPK terhadap Laporan Keuangan Pemerintah Daerah (LKPD) sejak tahun 2007 hingga 2011 menunjukkan bahwa sampai dengan tahun 2011 masih terdapat opini Tidak Memberikan Pendapat (TMP) sebanyak $18 \%$ dan Tidak Wajar (TW) sebanyak $2 \%$, sedangkan yang memperoleh opini Wajar Dengan Pengecualian (WDP) sebanyak 67\%. Sisanya opini Wajar Tanpa Pengecualian (WTP) hanya sebanyak $13 \%$. Sebagaimana tertuang dalam buku Ikhtisar Hasil Pemeriksaan BPK semester II tahun 2012, hasil pemeriksaan atas laporan keuangan kementerian/lembaga pada semester II tahun 2012 menunjukkan adanya 1.427 kasus kelemahan. Rendahnya kualitas laporan keuangan pemerintah daerah antara lain disebabkan oleh kurangnya pemahaman akuntansi dari penyusun laporan itu sendiri, pejabat/pelaksana yang bertanggung jawab belum melakukan pencatatan secara akurat dan tidak menaati ketentuan. Untuk menindaklanjuti hasil pemeriksaan BPK RI tersebut, maka jajaran akademisi perlu mengkaji secara mendalam pada salah satu pemerintah kabupaten/kota, dalam hal ini pemerintah kota Depok. Pengkajian dilakukan terbatas pada beberapa penyebab rendahnya kualitas laporan keuangan pemerintah daerah terkait dengan motivasi, kepuasan kerja dan komitmen penyusun laporan keuangan itu sendiri.

Hal ini juga sejalan dengan hasil analisis Badan Pengawasan Keuangan dan Pembangunan (BPKP). Deputi Kepala BPKP Bidang Pengawasan Penyelenggaraan Keuangan Daerah, Djadja Sukirman mengatakan bahwa sebagai dampak digulirkannya paket regulasi di bidang keuangan negara oleh pemerintah, mengharuskan setiap kepala daerah mempertanggungjawabkan pengelolaan APBD-nya dalam bentuk LKPD yang disusun sesuai dengan SAP. Laporan keuangan tersebut meliputi laporan realisasi anggaran, neraca, laporan arus kas, dan catatan atas laporan keuangan. Namun secara umum, terdapat beberapa faktor yang menyebabkan kualitas laporan keuangan kementerian/lembaga dan pemerintah daerah (pemda) rendah sehingga belum memperoleh opini WTP. Faktor-faktor ini antara lain karena penyajian yang belum sepenuhnya sesuai SAP, belum tertibnya pencatatan barang milik negara/daerah (BMD), dan kurangnya motivasi pegawai pengelola keuangan.

Laporan keuangan merupakan media informasi akuntansi untuk menyampaikan hasil kinerja pengelolaan keuangan kepada pihak pemangku kepentingan. Dengan demikian, agar dapat bermanfaat bagi para penggunanya, laporan keuangan harus memenuhi sejumlah kualitas tertentu. Pada kajian terhadap kinerja sumber daya manusia dalam mengelola dan menyusun laporan keuangan, umumnya dihubungkan dengan motivasi kerja dari sudut pandang produktivitas. Kinerja pegawai pemerintah sangat dipengaruhi oleh motivasi yang bukan hanya diukur secara finansial, tetapi ada yang lebih bersifat intrinsik. Salah satu faktor intrinsik adalah motivasi, yang secara langsung maupun tidak langsung dapat berpengaruh terhadap kinerja pegawai. Pegawai pemerintah dengan motivasi tinggi cenderung memiliki kepuasan kerja yang tinggi, yang pada 
akhirnya berkinerja tinggi. Pegawai dengan motivasi tinggi juga diharapkan memiliki komitmen kepada organisasi yang tinggi; cenderung memiliki kepuasan kerja yang tinggi, dan pada akhirnya berkinerja tinggi (Xiaohua, 2008).

Faktor lain dalam meningkatkan kinerja karyawan untuk mendapatkan laporan keuangan yang berkualitas antara lain adalah kepuasan kerja. Seseorang dapat dikatakan terlibat dalam suatu pekerjaan bila ia puas dengan pekerjaannya itu. Seseorang yang tidak puas dengan pekerjaannya hanya akan sedikit terlibat dalam pencapaian tujuan organisasinya (Knoop, 1995). Kepuasan kerja adalah sikap umum terhadap pekerjaan seseorang yang menunjukkan perbedaan antara jumlah penghargaan yang diterima pekerja dan jumlah yang mereka yakini seharusnya mereka terima (Robbins dan Judge, 2008). Kepuasan pegawai secara subyektif berasal dari kesimpulan yang berdasarkan pada perbandingan antara apa yang diterima pegawai dibandingkan dengan apa yang diharapkan dan diinginkan. Tinggi atau rendahnya motivasi dan kepuasan kerja karyawan pada suatu organisasi berdampak pada kualitas kinerja organisasi. Karyawan yang merasa puas dengan pekerjaannya, pada akhirnya dapat meningkatkan kualitas kinerjanya.

Tabel 1.

Perkembangan Opini LKPD Pemerintah Kota Depok Tahun 2005 sampai dengan 2011

\begin{tabular}{cl}
\hline Tahun & \multicolumn{1}{c}{ Opini LKPD } \\
\hline 2005 & Wajar Dengan Pengecualian \\
2006 & Wajar Dengan Pengecualian \\
2007 & Wajar Dengan Pengecualian \\
2008 & Wajar Dengan Pengecualian \\
2009 & Wajar Dengan Pengecualian \\
2010 & Wajar Dengan Pengecualian \\
2011 & Wajar Tanpa Pengecualian Dengan \\
& Paragraf Penjelas \\
2012 & Wajar Dengan Pengecualian \\
\hline
\end{tabular}

\section{Kajian Teori}

\subsection{Teori Dasar atas Kinerja Perusahaan}

Setiap pihak yang memiliki hubungan dengan perusahaan sangatberkepentingan dengan kinerja perusahaan. Pentingnya pengukuran kinerjaperusahaan dapat dijelaskan dengan dua teori yaitu teori keagenan (agency theory)dan teori pensinyalan (signalling theory). Dalam organisasi terdapat duapihak utama yang saling berhubungan yakni pemegang saham atau pemilik organisasi, dan manajemen organisasi. Pemegang saham disebut sebagai prinsipal, sedangkan manajemen adalah orang yang diberi kewenangan oleh pemegang saham untuk menjalankan organisasi atau perusahaan (biasa disebut agen) (Jensen dan Meckling, 1976). Menurut Berman (2006) hubungan keagenan ini mengakibatkan terjadinya informasi asimetris (asymmetry information), yakni manajemen secara umum memiliki lebih banyak informasi mengenai operasional dan posisi keuangan perusahaan daripada yang diketahui oleh pemilik. Terjadinya konflik kepentingan (conflict of interest) akibat ketidaksamaan tujuan, dimana manajemen tidak selalu bertindak sesuai dengan kepentingan pemilik.

Teori kedua yang menjelaskan pentingnya pengukuran kinerja adalah teoripensinyalan (signalling theory). Teori sinyal ini membahas bagaimana seharusnya sinyal-sinyal keberhasilan atau kegagalan manajemen (agen) disampaikan kepada pemilik (prinsipal) (Ross, 1979). Teori pensinyalan menjelaskan bahwa pemberian informasi oleh manajemen dilakukan untuk mengurangi informasi asimetris antara manajemen perusahaan dengan pihak luar. Salah satu caranya adalah dengan memberi informasi keuangan yang berkualitas dan dapat dipercaya kepada pihak luar sehingga dapat mengurangi informasi ketidakpastian mengenai kinerja perusahaan. Laporan keuangan yang berkualitas tentang kinerja perusahaan akan meningkatkan nilai organisasi.

\subsection{Kinerja Keuangan}

Pengukuran kinerja merupakan analisis yang digunakan perusahaan untukmelakukan perbaikan atas kegiatan operasional dan juga untuk dapat diperbandingkan dengan kinerja organisasi sejenis. Penilaian kinerja keuangan merupakan suatu kegiatan penting karena berdasarkan penilaian tersebut dapat dijadikan ukuran keberhasilan suatu perusahaan selama 
suatu periode tertentu sehingga dapat dijadikan pedoman bagi perbaikan atau peningkatan kinerja keuangan. Kinerja juga diartikan hasil atau tingkat keberhasilan seseorang secara keseluruhan selama periode tertentu di dalam melaksanakan tugas dibandingkan dengan berbagai kemungkinan seperti standar hasil kerja, target atau sasaran atau kriteria yang telah ditentukan terlebih dahulu dan telah disepakati bersama (Mangkuprawira, 2009).

Borman dan Motowidlo dalam Xiaohua (2008) menyatakan model Dua Dimensi untuk menjelaskan struktur kinerja individu, yaitu kinerja tugas (task performance) dan kinerja kontekstual (contextual performance). Kinerja tugas (task performance) adalah penyelesaian tugas-tugas dan tanggung jawab yang berhubungan dengan tugas yang diberikan, meliputi perilaku yang menghasilkan barang dan jasa atau pelayanan. Tugas-tugas tersebut adalah tugas-tugas yang diakui secara formal dan berbeda antara satu organisasi dengan organisasi yang lain. Kinerja kontekstual (contextual performance) menyatakan bahwa perilaku pekerjaan tidak hanya mendukung secara teknis suatu pekerjaan tertentu melainkan juga memberikan dukungan kepada organisasi secara lebih luas berkaitan dengan lingkungan sosial dan psikologis dimana secara teknis suatu pekerjaan seharusnya berlangsung. Task performance mempengaruhi efisiensi kerja secara langsung, sedangkan contextual performance bermanfaat pada pencapaian tujuan organisasi secara tidak langsung. Scotter dan Motowidlo dalam Xiaohua (2008) merinci aktivitas contextual performance secara umum terjadi pada semua jenis pekerjaan, dan meliputi dua dimensi:

a. Interpersonal facilitation, yaitu suatu perilaku yang berorientasi secara interpersonal dimana seseorang memberikan kontribusi kepada pencapaian tujuan organisasi.

b. Job dedication, menunjukkan perilaku disiplin seperti mematuhi peraturan, bekerja keras, dan mau berinisiatif untuk mengatasi permasalahan yang terjadi di tempat kerja.

\subsection{Motivasi}

Spencer (1993) menyatakan bahwa motives adalah drive, direct and select behavior toward certain actions or goals and away from others. Kata motif berkembang menjadi motivasi, yang berarti sedang digerakkan atau telah digerakkan oleh sesuatu, dan apa yang menggerakkan itu terwujud dalam suatu tindakan. Menurut Mitchell (1997), motivasi adalah proses yang menjelaskan intensitas, arah, dan ketekunan seorang individu untuk mencapai tujuannya. Faktor yang diperhitungkan untuk meningkatkan semangat dan gairah kerja pegawai dalam organisasi apapun adalah adanya motivasi dan kemampuan kerja yang dimiliki pegawainya.

Memotivasi pegawai bukan hanya dapat dilakukan dengan faktor eksternal saja, tetapi harus dilakukan dengan pendekatan intrinsik, salah satunya adalah meningkatkan motivasi yang berasal dari dalam. Motivasi dapat didefinisikan sebagai general altruistic motivation untuk melayani kepentingan suatu komunitas, negara atau masyarakat sebagaimana dinyatakan oleh Rainey dan Steinbauer dalam jurnal Galloping Elephants: Developing Elements of a Theory of Effective Government Organizations (1999). Perry dan Wise (1990) juga telah mendefinisikan motivasi sebagai kecenderungan individual untuk merespon terhadap motif-motif dasar yang unik dalam institusi.

Knoke dan Wright-Isak dalam Perry dan Wise (1990), membagi motivasi ke dalam tiga kategori yaitu motif rational, norm-based, dan affective. Motif rational melibatkan tindakan yang dilatarbelakangi oleh maksimisasi kepuasan individu (individual utility maximization), yaitu individu tertarik untuk bekerja karena memiliki kepentingan untuk mendukung sektor tertentu ketika ia memiliki kewenangan atau andil dalam perumusan kebijakan. Motif norm-based mengacu pada tindakan yang dihasilkan melalui usaha untuk menyesuaikan diri dengan norma. Motif norm-based didasarkan pada suatu keinginan untuk melayani kepentingan terhadap tugas. Sementara motif affective mengacu pada pemicu perilaku yang dilatarbelakangi oleh tanggapan emosi terhadap berbagai konteks sosial. Motif afektif didasarkan pada faktor emosional, yaitu komitmen terhadap sebuah program yang didasarkan atau suatu keyakinan mengenai manfaat sosialnya dan rasa patriotisme. Secara spesifik, Perry dan Wise (1990) menghipotesiskan bahwa:

1. Semakin tinggi motivasi yang dimiliki individu, maka semakin besar kemungkinannya bahwa ia akan tetap 
menjaga keanggotaannya di organisasi.

2. Motivasi berhubungan secara positif dengan kinerja individual di organisasi.

3. Organisasi yang memiliki anggota dengan motivasi yang tinggi akan mengurangi ketergantungannya terhadap penggunaan insentif yang berguna untuk mengelola kinerja organisasi secara efektif.

Xiaohua (2008) menyimpulkan bahwa motivasi memiliki lima dimensi yaitu:

1. Pemenuhan kebutuhan diri sendiri (selffulfillment).

2. Diberikan kewenangan pengambilan keputusan (policy-making).

3. Minat (interests).

4. Ketertarikan melayani (attraction to service).

5. Perasaan yang menunjukkan simpati (compassionate).

Dikaitkan dengan tiga kategori motif menurut Knoke dan Wright-Isak di atas, dimensi self-fulfilment dan policy making merupakan motif rasional; dimensi interests dan attraction to service merupakan motif norm-based;sedangkan dimensi compassionate merupakan motif affective. Sementara Wright (1990) menegaskan bahwa motivasi juga ditentukan oleh self-efficacy, yaitu penilaian individu yang bersangkutan bahwa yang bersangkutan merasa mampu melaksanakan pekerjaan tersebut atau tidak. Jika pegawai merasa memiliki kemampuan, maka mereka akan bekerja lebih keras, dan sebaliknya.

\subsection{Kepuasan Kerja}

Aktivitas manusia dalam mencapai tujuan dilatarbelakangi oleh perilaku individu, perilaku kelompok, dan perilaku sistem organisasi. Ketiga perilaku tersebut berdampak pada tinggi rendahnya produktivitas dan kinerja, tingkat kemangkiran, perputaran karyawan (turn over), dan kepuasan kerja. Robbins dan Judge (2008) mendefinisikan kepuasan kerja sebagai suatu perasaan positif tentang pekerjaan seseorang yang merupakan hasil evaluasi karakteristik-karakteristiknya.

Variabel terkait dengan pekerjaan atau organisasi yang berpengaruh terhadap kepuasan kerja meliputi: gaji, benefits, lingkungan kerja secara fisik, masalah keamanan (safety), kesempatan untuk promosi, dan rekan kerja (Tanner, 2007). Mottaz dan Potts dalam Tanner (2007) mengembangkan perceived reward model yang menyatakan lima reward yang diyakini mempengaruhi kepuasan kerja, yaitu:

1. Atasan (supervisors).

2. Rekan sejawat (coworkers).

3. Kondisi kerja (working conditions).

4. Gaji (salary).

5. Kesempatan promosi (promotional opportunities).

Sementara Hackman dan Oldham dalam Tanner (2007) mengajukan model kepuasan kerja lima faktor yang lain terkait dengan pekerjaan itu sendiri:

1. Variasi keterampilan (skill variety).

2. Identitas tugas (task identity).

3. Signifikansi tugas (task significance).

4. Otonomi (autonomy).

5. Umpan balik (feedback).

Mason dalam Xiaohua (2008) menggambarkan ukuran kepuasan kerja adalah apakah pegawai pemerintah merasa puas terhadap hal-hal berikut:

1. Tantangan pekerjaan (job challenge).

2. Umpan balik yang dibutuhkan (feedback needed).

3. Pembayaran yang diterima (payment).

4. Rekan kerja (coworkers).

5. Keadilan (fairness).

6. Supervisi (supervisions).

7. Evaluasi kinerja (performance evaluation).

8. Rasa hormat (respect).

9. Segala perasaan tentang pekerjaan (overall feeling about job).

10.Segala perasaan tentang organisasi (overall feeling about organization).

\subsection{Komitmen}

Griffin (2005) menyatakan komitmen adalah sikap yang mencerminkan sejauhmana seseorang mengenal dan terikat pada organisasinya. Mowday, Porter dan Steers (2006) menyatakan bahwa komitmen adalah kuatnya pengenalan dan keterlibatan seseorang dalam suatu organisasi tertentu. Komitmen sebagai suatu kepercayaan terhadap nilai-nilai organisasi (identification), kesediaan untuk berusaha sebaik mungkin demi kepentingan organisasi (job involvement), dan keinginan untuk tetap menjadi anggota organisasi bersangkutan (loyalty) yang dinyatakan oleh seorang pegawai terhadap organisasinya.

Pegawai yang memiliki komitmen akan bekerja dengan penuh dedikasi untuk kepentingan organisasi karena pegawai yang 
memiliki komitmen tinggi menganggap bahwa hal penting yang harus dicapai adalah pencapaian tugas dalam organisasi. Pegawai yang memiliki komitmen yang tinggi juga memiliki pandangan yang positif dan akan melakukan yang terbaik untuk kepentingan organisasi.

Pegawai yang mempunyai komitmen akan mampu menunjukkan peningkatan efektivitas organisasi. Hal ini ditunjukkan melalui tingkat tingginya pencapaian kinerja, kualitas pekerjaan dan antara lain juga mengurangi keterlambatan kerja, ketidakhadiran serta perputaran keluar masuknya (turn over) karyawan (Mathieu dan Zajac dalam Fletcher, 2012). Makna komitmen adalah tingkat kepercayaan dan penerimaan tenaga kerja terhadap tujuan organisasi dan mempunyai keinginan untuk tetap ada di dalam organisasi yang pada akhirnya tergambar dalam statistik ketidakhadiran serta perputaran keluar masuknya tenaga kerja. Komitmen pegawai dalam organisasi pemerintah berbeda dengan organisasi swasta. Mathieu dan Zajac dalam Kelechikwu(2012) dalam studi meta analisisnya menemukan bahwa komitmen pegawai di organisasi pemerintah memiliki korelasi positif dengan kehadiran di tempat kerja serta kesediaan untuk menyelesaikan tugas-tugas secara sukarela dan tidak berhubungan dengan turn over karyawan.

Perbedaan lain terkait komitmen pegawai di sektor pemerintah dikemukakan oleh Goulet dan Frank dalam Borchers (2006) berdasarkan hasil penelitiannya bahwa komitmen pegawai di swasta lebih mengarah kepada karir pribadinya, sedangkan pegawai di organisasi pemerintah lebih kepada loyalitas kepada organisasinya. Komitmen pegawai pada organisasi pemerintah lebih berkaitan dengan attitudinal commitment dan kesediaan (willingness). Meyer dan Allen (2007) mencoba untuk mengintegrasikan berbagai definisi komitmen tersebut dengan membuat model komitmen yang terdiri tiga komponen, yaitu:

1. Affective commitment (komitmen afektif), yaitu keterikatan karyawan secara psikologis kepada organisasi yang bersifat positif. Artinya bahwa karyawan tersebut mengafiliasikan dirinya dengan tujuan organisasi dan tetap ingin menjadi bagian dari organisasi tersebut.

2. Continuance commitment (komitmen berkelanjutan), yaitu suatu komitmen yang 'mengharuskan' seseorang untuk tetap menjadi anggota organisasi dengan alasan bahwa biaya yang harus ditanggung (baik economic cost maupun social cost) lebih tinggi jika ia keluar dari organisasi (side bet theory).

3. Normative commitment (komitmen normatif), komitmen individual untuk tetap menjadi anggota organisasi, lebih karena adanya suatu kewajiban moral. Sebagai contoh ketika sebuah organisasi telah memberikan pelatihan ataupun investasi dalam pengembangan sumber daya manusia anggota organisasinya maka anggota organisasi tersebut cenderung merasa memiliki kewajiban 'moral' untuk tetap menjadi anggota organisasi dalam rangka 'membayar hutang'. Jadi anggota organisasi berkomitmen terhadap organisasi karena merasa 'seharusnya' memiliki komitmen tersebut.

Ketiga komponen komitmen tersebut tidak bersifat mutually exclusive, artinya bahwa seseorang bisa memiliki affective commitment, continuance commitment maupun normative commitment secara simultan atau dalam waktu yang bersamaan dengan tingkat intensitas yang berbeda-beda.

\subsection{Kualitas Laporan Keuangan Pemerintah Daerah}

Salah satu bentuk kinerja dalam pengelolaan keuangan daerah adalah laporan keuangan daerah yang berkualitas. Kualitas ini dicerminkan dari opini yang diberikan oleh BPK. Jenis-jenis opini BPK terhadap LKPD berdasarkan UU Nomor 15 Tahun 2004 adalah (i) opini wajar tanpa pengecualian (unqualified opinion), (ii) opini wajar dengan pengecualian (qualified opinion), (iii) opini tidak wajar (adversed opinion), dan (iv) pernyataan menolak memberikan opini (disclaimer of opinion). Pencapaian opini yang baik ini merupakan kinerja organisasi yang merupakan kinerja individu secara kolektif dalam pengelolaan keuangan daerah sehingga kinerja organisasi dapat merepresentasikan kinerja para individu yang terlibat di dalamnya.

$2010 \begin{gathered}\text { Peraturan Pemerintah Nomor } 71 \text { Tahun } \\ \text { menjelaskan karakteristikkualitatif }\end{gathered}$ laporan keuangan adalah ukuran-ukuran normatif yang perludiwujudkan dalam informasi akuntansi sehingga dapat memenuhi 
tujuannya. Adapun karakteristik kualitatif laporan keuangan pemerintah yang berikut ini merupakan prasyarat normatif yang diperlukan agar laporan keuangan pemerintah dapat memenuhi kualitas yang dikehendaki:

1. Relevan.

1) Memiliki manfaat umpan balik (feedback value).

2) Memiliki manfaat prediktif (predictive value).

3) Tepat waktu (timeliness).

4) Lengkap.

2. Andal.

1) Penyajian jujur.

2) Dapat diverifikasi (verifiability).

3) Netralitas.

3.. Dapat dibandingkan.

4. Dapat dipahami.

\subsection{Kekuasaan Pengelolaan Keuangan Daerah}

Sesuai pasal 5 Peraturan Menteri Dalam Negeri (PMD) Nomor 13 Tahun 2006, dalam rangka melaksanakan pengelolaan keuangan daerah, Kepala Daerah selaku kepala pemerintah daerah adalah pemegang kekuasaan pengelolaan keuangan daerah dan mewakili pemerintah daerah dalam kepemilikan kekayaan daerah yang dipisahkan. Kepala daerah melimpahkan sebagian atau seluruh kekuasaannya kepada: (a) sekretaris daerah selaku kordinator pengelola keuangan daerah; (b) kepala Satuan Kerja Pengelola Keuangan Daerah (SKPKD) selaku Pejabat Pengelola Keuangan Daerah (PPKD); dan (c) kepala Satuan Kerja Perangkat Daerah (SKPD) selaku pejabat pengguna anggaran/ pengguna barang.

Pelaksanaan sistem akuntansi dan pelaporan keuangan daerah untuk tingkat pemerintah daerah dilakukan oleh PPKD yang dapat dilimpahkan kepada pejabat lainnya di lingkungan SKPKD (PMD Nomor 13 Tahun 2006 pasal 7), sedangkan pelaksanaan akuntansi SKPD dilakukan oleh Pejabat Penatausahaan Keuangan (PPK) SKPD. PPK - SKPD mengkordinasikan pelaksanaan sistem dan prosedur penatausahaan bendahara penerimaan dan bendahara pengeluaran (PMD Nomor 13 Tahun 2006 pasal 234). Pada akhirnya pelaksanaan sistem akuntansi pemerintah daerah akan menghasilkan kinerja berupa kualitas laporan keuangan. Pejabat di lingkungan SKPD-SKPD dan SKPD terdiri dari:

1. PPKD atau pejabat lain yang ditunjuk, yang biasanya setingkat eselon III dan stafnya di SKPKD, yang melaksanakan sistem akuntansi di tingkat pemerintah daerah;

2. PPK-SKPD dan stafnya, yang melaksanakan sistem akuntansi di tingkat SKPD atau Dinas;

3. Bendahara Penerimaan, yang melaksanakan penatausahaan penerimaan pendapatan daerah di tingkat SKPD;

4. Bendahara Pengeluaran, yang melaksanakan penatausahaan pengeluaran daerah di tingkat SKPD.

\section{Metode Penelitian}

Metode penelitian adalah cara ilmiah yang digunakan untuk mendapatkan data dengan tujuan dan kegunaan tertentu (Sugiyono, 2012). Metode penelitian yang digunakan dalam penelitian ini adalah metode kuantitatif yang bersifat deskriptif. Sementara untuk obyek penelitian adalah apa yang menjadi titik perhatian dari suatu penelitian, sedangkan tempat dimana obyek melekat merupakan subyek penelitian (Arikunto, 2006). Obyek penelitian dalam penelitian ini adalah SKPD dan SKPKD di Kota Depok.

Jenis data yang digunakan dalam penelitian ini adalah data primer, yaitu data yang diperoleh langsung dari sumber pertama, misalnya individu atau perorangan (Umar, 2002). Dalam penelitian ini data primer diperoleh dari responden yaitu: para pegawai SKPD dan SKPKD pemerintah kota Depok. Untuk data sekunder diperoleh dengan cara melakukan kajian studi pustaka seperti literatur dan referensi yang berkaitan dengan sumber-sumber lain di luar organisasi yang dapat mendukung penelitian, dalam hal ini berdasarkan buku Ikhtisar Hasil Pemeriksaan BPK semester II tahun 2012. Sedangkan sumber data yang dipakai dalam penelitian ini adalah data subyek, yaitu data yang berupa opini, sikap, pengalaman atau karakteristik dari seseorang atau kelompok orang yang menjadi subyek penelitian (responden).

Populasi dalam penelitian ini adalah pegawai yang bertanggung jawab dalam pengelolaan keuangan daerah dalam pelaksanaan sistem akuntansi pada SKPD dan SKPKD di kota Depok. Jumlah SKPD di kota Depok sebanyak 38 unit kerja dan 1 unit 
kerja SKPKD, sehingga totalnya 39 unit kerja. Setiap unit SKPD terdapat antara 4-6 orang yang bertanggung jawab dalam pelaksanaan akuntansi.

\section{Hasil Penelitian dan Pembahasan}

Jumlah minimal sampel ditentukan dengan menggunakan rumus Slovin (Riduwan, 2008, Umar, 2008; dan Sarwono, 2006). Jumlah kuesioner yang dikirim sebanyak 170 lembar atau 130 persen dari jumlah sampel yang dibutuhkan guna mengantisipasi kemungkinan respon kurang dari 100 persen dan yang diisi tidak lengkap. Jumlah sampel yang kembali sebanyak 139 kuesioner atau sebanyak 81,76\%. Namun yang terisi secara lengkap dan dapat digunakan dalam penelitian ini berjumlah 131 responden atau $77,06 \%$. Dalam analisis SEM tidak ada alat uji statistik tunggal untuk mengukur atau menguji hipotesis mengenai model (Bollen dan Long dalam Wijanto, 2008). Pada umumnya berbagai jenis fit index digunakan untuk mengukur derajat kesesuaian antara model yang dihipotesiskan dengan data yang disajikan. Peneliti diharapkan untuk melakukan pengujian dengan menggunakan beberapa fit index dalam mengukur kebenaran model yang diajukannya. Hasil pengujian indeks kesesuaian dan cut-off value-nya untuk menguji apakah sebuah model dapat diterima atau ditolak disajikan pada Tabel di bawah ini :

Tabel 2.

Evaluasi Goodnessof Fit Indices

\begin{tabular}{cccc}
\hline $\begin{array}{c}\text { Goodness of Fit } \\
\text { Indeces }\end{array}$ & Hasil Model & Cut-off Value & Keterangan \\
\hline$X^{2}$ Chi-Square & $X^{2}$ Chi-Square $=331,09$ & P value $\geq 0,05$ & Tidak Fit \\
& $P=0,00243$ & & \\
RMSEA & 0,042 & $\leq 0,08$ & Fit \\
GFI & 0,85 & $\geq 0,90$ & Cukup Fit \\
AGFI & 0,81 & $\geq 0,90$ & Cukup Fit \\
CMIN/DF & 1,63 & $\leq 2,00$ & Fit \\
CFI & 0,99 & $\geq 0,90$ & Fit \\
NFI & 0,96 & $\geq 0,90$ & Fit \\
NNFI & 0,99 & $\geq 0,90$ & Fit \\
RFI & 0,95 & $\geq 0,90$ & Fit \\
IFI & 0,99 & $\geq 0,90$ & Fit \\
\hline
\end{tabular}


Berdasarkan Pengujian Model Persamaan Struktural Model struktural adalah model mengenai struktur hubungan yang membentuk atau menielaskan kausalitas antara faktor. Berikut ini model persamaan struktural hasil pengujian menggunakan bantuan program komputer Lisrel.

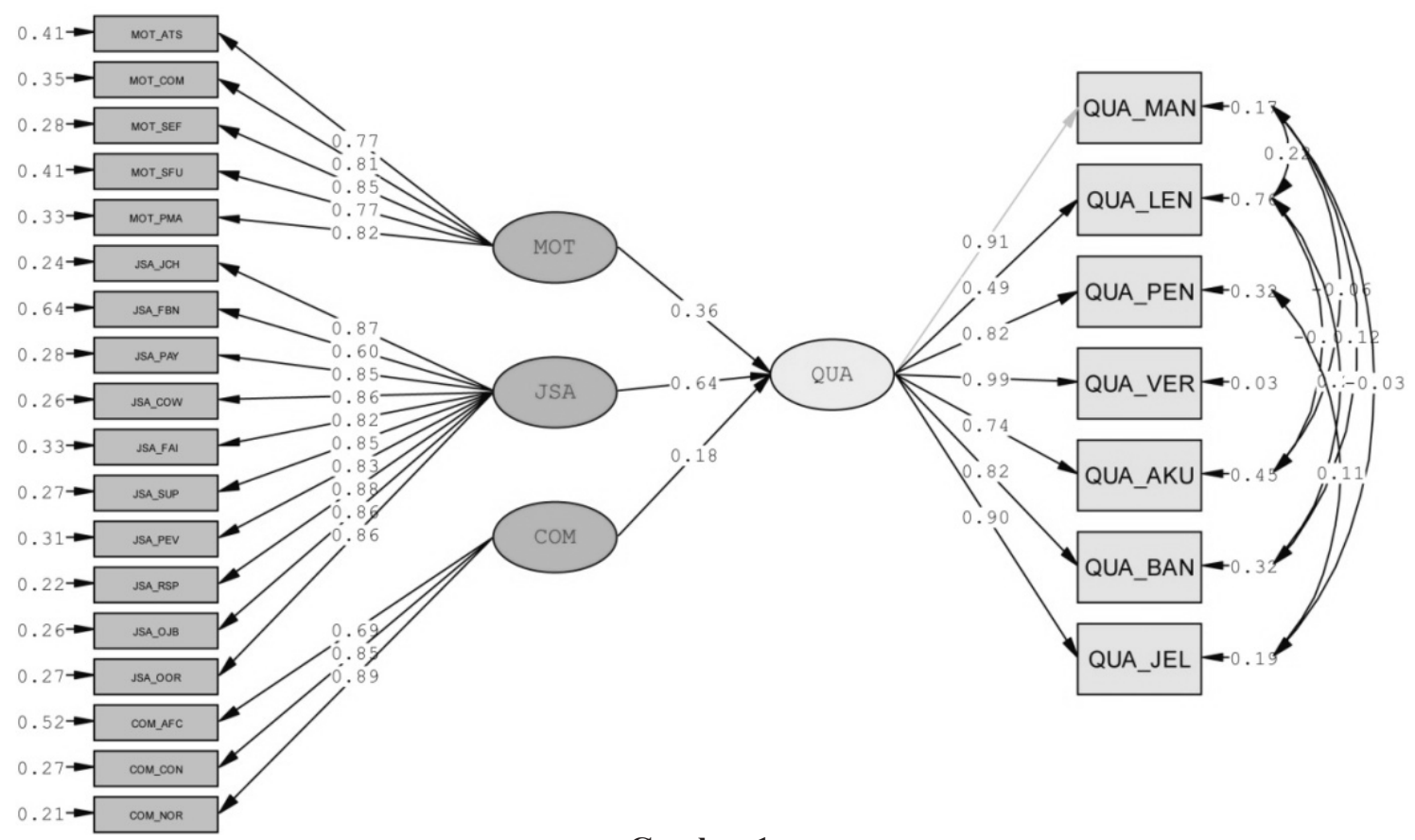

Gambar 1.

Hasil Pengujian Model Persamaan Struktural

Berdasarkan gambaran model hubungan antarvariabel dalam tabel berikut. persamaan struktural di atas, disajikan ringkasan

Tabel 3.

Hasil Pengujian Korelasi

\begin{tabular}{ccccc}
\hline \multicolumn{2}{c}{ Hubungan Variabel } & Estimate & S. E. & t hitung \\
\hline Kualitas $\leftarrow$ & Motivasi & 0,36 & 0,060 & 5,93 \\
Kualitas $\leftarrow$ & Kepuasan kerja & 0,64 & 0,069 & 9,27 \\
Kualitas $\leftarrow$ & Komitmen & 0,18 & 0,057 & 3,25 \\
\hline
\end{tabular}

Persamaan strukturalnya adalah:

$\mathrm{QUA}=0,36 \mathrm{MOT}+0,64 \mathrm{JSA}+0,18 \mathrm{COM}$

Keterangan:

MOT = variabel Motivasi

JSA $=$ variabel Kepuasan Kerja

$\mathrm{COM}=$ variabel Komitmen

$\mathrm{SE}=$ standard error

Hipotesis 1 menduga bahwa terdapat pengaruh signifikan antara motivasi pegawai akuntansi terhadap kualitas laporan keuangan pemerintah daerah secara parsial. Adapun berdasarkan hasil pengujian ditemukan bahwa hubungan yang terjadi adalah positif dan signifikan antara motivasi dengan kualitas laporan keuangan. Dengan nilai sebesar 0,36 (t hitung 5,93) yang berarti lebih kecil dari angka standar signifikansi pada $\alpha=5 \%$ yakni sebesar 1,96 . Hasil pengujian ini menunjukkan bahwa jika motivasi pegawai akuntansi meningkat maka kualitas laporan keuangan juga akan meningkat dan signifikan dengan asumsi faktor lainnya tetap. Hasil pengujian ini mendukung penelitian Sumarti (2007) yang menyatakan bahwa motivasi berpengaruh langsung terhadap kepuasan kerja. Hal ini dapat berarti juga bahwa motivasi mempengaruhi komitmen organisasi, yang pada gilirannya akan mendukung kualitas laporan keuangan. 
Murty, et al. (2012) menyatakan kinerja karyawan bagian akuntansi (studi kasus pada perusahaan manufaktur di Surabaya) dapat dilihat dari seberapa besar motivasi yang diberikan perusahaan kepada karyawan. Karyawan mengidentifikasikan dirinya dan melibatkan diri dengan organisasinya, yang berarti membuat komitmen secara organisasi kepada perusahaan. Seseorang yang mempunyai motivasi yang tinggi terhadap pekerjaannya cenderung untuk melakukan pekerjaannya dengan baik dan maksimal.

Hipotesis 2 menduga bahwa terdapat pengaruh signifikan antara kepuasan kerja pegawai akuntansi terhadap kualitas laporan keuangan pemerintah daerah secara parsial. Adapun berdasarkan hasil pengujian ditemukan bahwa hubungan yang terjadi adalah positif dan signifikan antara kepuasan kerja dengan kualitas laporan keuangan, dengan nilai sebesar 0,64 (t hitung 9,27) yang berarti lebih kecil dari angka standar signifikansi pada $\alpha=5 \%$ yakni sebesar 1,96. Hasil pengujian ini menunjukkan bahwa jika kepuasan kerja meningkat maka kualitas laporan keuangan juga akan meningkat dan signifikan dengan asumsi faktor lainnya tetap.

Sejalan dengan ini, penelitian Devi (2009) tentang analisis pengaruh kepuasan kerja dan motivasi terhadap kinerja karyawan dengan komitmen organisasi sebagai variabel intervening pada karyawan alih daya menunjukkan bahwa variabel kepuasan kerja berpengaruh signifikan positif terhadap komitmen organisasi, namun variabel motivasi menunjukkan hasil yang tidak signifikan positif terhadap komitmen organisasi. Lebih lanjut, variabel kepuasan kerja dan motivasi menunjukkan pengaruh signifikan positif terhadap kinerja karyawan yang tercermin dalam kualitas laporan keuangan yang dibuatnya.

Hipotesis 3 menduga bahwa terdapat pengaruh signifikan antara komitmen pegawai akuntansi terhadap kualitas laporan keuangan pemerintah daerah secara parsial. Adapun berdasarkan hasil pengujian ditemukan bahwa hubungan yang terjadi adalah positif dan signifikan antara komitmen dengan kualitas laporan keuangan, dengan nilai sebesar 0,18 (t hitung 3,25) yang berarti lebih kecil dari angka standar signifikansi pada $\alpha=5 \%$ yakni sebesar 1,96. Hasil pengujian ini menunjukkan bahwa jika komitmen meningkat maka kualitas laporan keuangan juga akan meningkat dan signifikan dengan asumsi faktor lainnya tetap. Hasil pengujian di atas mendukung analisis Kurnia (2013) yang menyatakan terdapat pengaruh positif antara kompetensi pegawai dan komitmen organisasi terhadap kualitas laporan keuangan Satuan Kerja Perangkat Daerah di kota Bandung masing-masing sebesar $41,8 \%$ dan 37,6\%. Namun hal ini bertolak belakang dengan penelitian Dwiyusufadi (2013) yang mendapatkan hasil bahwa komitmen organisasi tidak berpengaruh signifikan terhadap kualitas informasi laporan keuangan.

Hipotesis 4 menduga bahwa terdapat pengaruh signifikan antara motivasi, kepuasan kerja dan komitmen pegawai akuntansi terhadap kualitas laporan keuangan pemerintah daerah secara simultan. Berdasarkan hasil pengujian ditemukan bahwa hubungan yang terjadi adalah positif dan signifikan antara motivasi, kepuasan kerja dan komitmen secara simultan dengan kualitas laporan keuangan. Berdasarkan uji Lisrel, dikatakan jika salah satu dari variabel laten eksogensignifikan dan positif terhadap variabel laten terikat endogen maka secara simultan dikatakan seluruh variabel motivasi, kepuasan kerja dan komitmen secara simultan hubungan yang terjadi adalah positif dan signifikan dengan kualitas laporan keuangan. Adapun berdasarkan uji SPSS, berikut disajikan tabel Anova dan Coefficients yang memperkuat hipotesis 4 di atas.

Tabel 4.

Anova

\begin{tabular}{llccccc}
\hline & Model & Sum of Squares & df & Mean Square & F & Sig. \\
\hline 1 & Regression & 930.537 & 3 & 310.179 & 74.417 & $.000^{\text {a }}$ \\
Residual & 529.349 & 127 & 4.168 & & \\
Total & 1459.885 & 130 & & & \\
\hline
\end{tabular}

a. Predictors: (Constant), komitmen, kepuasan kerja, motivasi

b. Dependent Variable: kuailtas laporan 
Tabel 5.

Coefficient

\begin{tabular}{lccccc}
\hline \multicolumn{1}{c}{ Model } & $\begin{array}{c}\text { Unstandardized } \\
\text { Coefficients B }\end{array}$ & Std. Error & $\begin{array}{c}\text { Standardized } \\
\text { Coefficients } \\
\text { Beta }\end{array}$ & $\mathbf{t}$ & Sig. \\
\hline $1 \quad$ (Constant) & 9.877 & 1.593 & & 6.201 & .000 \\
Motivasi & .348 & .051 & .368 & 6.785 & .000 \\
Kepuasan Kerja & .320 & .027 & .648 & 11.948 & .000 \\
Komitmen & .218 & .066 & .178 & 3.310 & .001 \\
\hline
\end{tabular}

a. Dependent Variable : kualitas laporan

Berdasarkan uji F, didapat nilai Sig 0,000 lebih rendah dari nilai angka standar signifikansi pada $\alpha=5 \%$ yakni sebesar 1,96 . Berdasarkan hasil uji $\mathrm{F}$ pada tabel Anova mendapatkan nilai 74,417, yang berarti lebih besar dari tabel $\mathrm{F}$ pada nilai angka standar signifikansi pada $\alpha=5 \%$ yakni 2,44 . Hasil pengujian ini menunjukkan bahwa jika motivasi, kepuasan kerja dan komitmen meningkat maka kualitas laporan keuangan juga akan meningkat dan signifikan. Hasil pengujian di atas mendukung penelitian Malikha Widyasari (2011). Dari analisis dan perhitungan yang telah dilakukan, didapat hasil dan kesimpulan bahwa variabel orientasi etika, komitmen profesional, pengalaman audit, kepuasan kerja dan motivasi mempunyai pengaruh yang positif dan signifikan terhadap kualitas hasil kerja dalam hal ini auditor internal dan eksternal.

\section{Simpulan, Keterbatasan dan Implikasi Hasil Penelitiant}

Berdasarkan hasil pengujian ditemukan bahwa secara parsial, masing-masing variabel motivasi, kepuasan kerja dan komitmen berhubungan positif dan berpengaruh signifikan dengan kualitas laporan keuangan. Dari hasil pengujian di atas, juga terbukti bahwa secara simultan variabel motivasi, kepuasan kerja dan komitmen berhubungan positif dan berpengaruh signifikan terhadap variabel kualitas laporan keuangan pemerintah daerah. Secara bersama-sama dan signifikan ketiga variabel ini saling mendukung dan berpengaruh dalam meningkatkan kualitas laporan keuangan pemerintah daeerah.

Dari simpulan dan keterbatasan penelitian ini, saran yang dapat disampaikan adalah dapat dilakukan perubahan atau penambahan variabel penelitian yang disesuaikan dengan kapabilitas variabel pemerintah daerah/kota sehingga hasil analisis penelitian akan lebih beragam dan dapat menambah gagasan baru dalam penelitian yang akan datang seperti kompetensi yang harus dimiliki oleh para pengelola keuangan yang mencakup antara lain aspek pengetahuan SAP (knowledge), kemahiran dan keterampilan (skill) serta sikap perilaku (attitude), atau intensitas pelatihan, etika. Dengan demikian dapat diperoleh hasil penelitian lebih beragam dalam rangka tujuan peningkatan kualitas laporan keuangan sesuai dengan karakter masing-masing pemerintah daerah/kota. Dapat ditambahkan juga saran bahwa penelitian yang dilakukan tidak hanya pada SKPD, SKPKD kota Depok saja akan tetapi dapat menggunakan study comparative, internalisasi nilai-nilai berorientasi pada pelayanan publik, peningkatan pemahaman penyusunan pelaporan laporan keuangan dengan pendidikan dan pelatihan untuk beberapa pemerintah daerah/ kota yang ada di area Jabodetabek bahkan di

\section{Daftar Pustaka}

Arikunto, Suharsimi. 2006. Prosedur Penelitian: Suatu Pendekatan Praktik, PT Rineka Cipta, Jakarta.

Berman, E. M., et al. 2006. Human Resource Management in Public Service: Paradoxes, Processes, and Problems. Second Edition. Sage Publication Inc.

Borchers, B. J. 2006. Workplace Environment Fit, Commitment, and Job Satisfaction in a 


\section{Nonprofit}

Devi, Eva Kris Diana. 2009. Analisis Pengaruh Kepuasan Kerja dan Motivasi Terhadap Kinerja Karyawan dengan Komitmen Organisasional Sebagai Variabel Intervening. Tesis Magister Manajemen, Universitas Diponegoro. Semarang.

Dwiyusufadi, Seno. 2013. Pengaruh Kapasitas Sumber Daya Manusia, Pemanfaatan Teknologi Informasi, dan Komitmen Organisasi Terhadap Kualitas Informasi Laporan Keuangan Pemerintah Daerah Kota Bandung. Universitas Pendidikan Indonesia. Bandung.

Fletcher, D. E. 2012. Effects Of Organizational Commitment, Job Involvement, And Organizational Culture On The Employee Voluntary Turnover Process.

Jensen, Michael C., dan Meckling, William H. 1976. Theory of The Firm: Managerial Behavior, Agency Costs and Ownership Structure. Journal of Financial Economics 3, pp. 305-360. Q North-Holland Publishing Company. University of Rochester, Rochester, NY 14627, U.S.A. Received January 1976, revised version received July 1976.

Kelechikwu Emmanuel, O. 2012. Mastering The Art of Sustainability Business Competitiveness. Trafford Publishing.

Knoop, R. 1995. Relationships between Job Involvement, Job Satisfaction and Organizational Commitment for Nurses. Journal of Psychology Interdisciplinary and Applied Psychology, 129(6), 643-649.

Kurnia, Ika Famela 2013. Pengaruh Kompetensi Pegawai dan Komitmen Organisasi Terhadap Kualitas Laporan Keuangan Satuan Kerja Perangkat Daerah (SKPD) di Kota Bandung. Universitas Pendidikan Indonesia. Bandung.

Mangkuprawira, S. 2009. Horison Bisnis, Manajemen, dan Sumber Daya Manusia. IPB Press. Bogor.

Meyer, J. P. dan Allen, N. J. 2007. A Three-Component Conceptualization of Organizational Commitment: Some Methodological Considerations. Human Resource Management Review, 1, pp. 6198.

Mitchell, T. R. 1997. Research in Organizational Behavior. Greenwich, CT: JAI Press, hal. 60-62.

Mowday, R., Porter, L., dan Steers, R. 2006.
Employee Organization Linkages. New York: Academic Press.

Murty, Windy Aprilia dan Hudiwinarsih, Gunasti. Pengaruh Kompensasi, Motivasi dan Komitmen Organisasional Terhadap Kinerja Karyawan Bagian Akuntansi (Studi Kasus pada Perusahaan Manufaktur di Surabaya). The Indonesian Accounting Review Volume 2. Number 2, July 2012.

Republik Indonesia. 2004. Undang-undang Nomor 15 Tahun 2004 tentang Pemeriksaan Pengelolaan dan Tanggung Jawab Keuangan Negara. Jakarta. 2010. Peraturan Pemerintah Nomor 71 Tahun 2010 tentang Standar Akuntansi Pemerintahan. Jakarta.

2011. Peraturan Menteri Dalam Negeri Nomor 13 Tahun 2006 tentang Pedoman Pengelolaan Keuangan Daerah yang telah diubah beberapa kali terakhir dengan PMD Nomor 21 Tahun 2011. Jakarta.

Robbins, S. P., dan Judge, T. A. 2008. Perilaku Organisasi Buku 1. Edisi Bahasa Indonesia. Jakarta. Salemba Empat.

Ross, S.A, 1976. The Determination of Financial Structure: The IncentiveSignalling Approach. Bell Journal of Economics. Volume 8, p 23-40.

Sugiyono. 2012. Metode Penelitian Kuantitatif, Kualitatif, dan Kombinasi (Mixed Methods) Penelitian Bisnis. Penerbit CV Alfabeta. Bandung.

Sumarti, Titik. 2007. Pengaruh Motivasi Terhadap Komitmen Organisasional Melalui Kepuasan kerja (Studi pada Perawat Instalasi Rawat Inap I RSU Dr. Saiful Anwar Malang). Fakultas Ekonomi Universitas Negeri Malang. Malang.

Umar, Husein. 2008. Desain Penelitian Akuntansi Keperilakuan. PT Rajagrafindo Persada. Jakarta.

Perry, J. L., dan Wise, L. R. 1990. The Motivational Bases of Public Service. Public Administration Review, Volume 50, Number 3 (May-Jun., 1990), pp. 367-373.

Wijanto, S. H. 2008. Structural Equation Modeling dengan LISREL 8.8 Konsep \& Tutorial. Graha Ilmu. Yogyakarta.

Wright, B. E. 2003. Toward Understanding Task, Mission and Public Service Motivation: A Conceptual and Empirical Synthesis of Goal Theory and Public Service Motivation. Washingthon DC.7th National Public Management Research Conference, 
Georgetown Public Policy Institute, Georgetown University, Washington, D.C.

Xiaohua, L. 2008. An Empirical Study on Public Service Motivation and the Performance of Government Employee in China. Canadian Social Science, Volume 4, Number 2. 